\title{
NGOs and Their Implications in Promoting Social Development in Bangladesh: An Overview
}

\author{
A.B.M Enamol Hassan \\ Department of Humanities, Chittagong University of Engineering and Technology (CUET), Chittagong-4349, Bangladesh \\ *Corresponding Author: enamsoc@cuet.ac.bd
}

Copyright (C) 2015 Horizon Research Publishing All rights reserved.

\begin{abstract}
As the non-profit sector of a country, Non Government Organizations (NGOs) are truly vital cog in the paradigm of social development in Bangladesh. It is generalized that Civil Society Organizations (CSOs) and NGOs have created jointly a new era of partnership in poverty alleviation activities, gender sensitive issues, education, health and been giving competent sustainability in the socio-economic conditions of Bangladesh.Since the NGOs are aimed to spreading awareness in people, strengthening and institutionalization of democracy promotion as well as ensuring maximum people participation in community- driven development approach. Therefore,the paper reviews these developmental phenomena launched by local and international NGOs in the context of Bangladesh especially in the field of education, health, environment, micro-finance, good governance, democracy and social justice etc. It investigates their contribution and present status along with necessary critical evaluations as well as factors that sometimes underestimate of NGOs' existence. The paper is designed with a theoretical conception of development contributed by NGOs along with its location in civil society and is fully literature-based that data and information have been accumulated from books, journals and electronic media as well. As the finding it has been seen that the sector is working for ensuring socio-economic development of poor and hard core poor people those are treated as the very negligible and marginalized by other two sectors i.e state and business working with political implications and profit maximization respectively whereas NGOs do for poors in assurance of financial solvence, basic education, nutritional status, participation in decision making for women both inside and outside of family and good governance etc. After all their activities are on the ground of no generation of profit.
\end{abstract}

Keywords Non-government Organization, Civil Society, Education; Health; Micro-credit, Poverty, Development

\section{Introduction}


third sector of a country [44].In a nut shell, NGOs have great potentiality to do work as contractor or non-profit making supporting body of local and national government for these services. Many NGOs are now efficiently engaged in providing counseling, special education, and personal assistance service areas which are the primary responsibility of local government but sometimes unsuccessful in doing these properly [52].After all, it should be recapitulated that NGOs sometimes,as a part of civil society, almost capable to meet the needs of poor people strengthening social development and keeping role to make a bridge between local people and central government about their rights and claims.

\section{Major Objective of the Study}

As the endeavor of exhibiting the main implications of NGOs, the paper tries to contain a rich mixture of analytical descriptions of voluntary organizations that contribute and emerge as the vital force of social development in Bangladesh. It follows the sort of research questions since the wording of research questions determines the focus and scope of the study[23].

\section{Research Questions}

- when do the NGOs actually starts its operation in Bangladesh?

- what kinds of programmes do the NGOs operate?

- How do they operate programmes? Who are the actual target groups of NGOs?

- Do they meet their goals?

- Do NGOs play a vital role in reducing poverty?

- Is NGOs' existence important for the society?

- Do NGOs' functionings/roles undergo in anykind of criticism/controversy?

\section{Sources of Data and Methodology}

We have used the source of secondary data collection method from the documents published in prints and electronics(i.e books, articles, journals,NGOs' reports, webpage and so on).We also tried to accumulate data and information from UNDP database for making rich this paper. Moreover, we searched with bonafied efforts in world Bank, Bangladesh Statistical Yearbooks, Bangladesh NGO Bureau and some other largest NGOs working in Bangladesh etc.Finally, in the exercise of social development, we depicted the role of NGOs in socio-economic aggregates of Bangladesh.

\section{Theoretical Assumptions}

The world Bank(WB) thinks social development means the giving priority to poor people by listening and promoting their voices, ensuring participation in the overall development process. The whole process of social development should subject to understand and address their (poor)needs, aspirations by building formal and informal institutions like NGOs and civil society. Very exclusively in social development, WB adopts an approach that focuses on the needs to "put people first" which empowers people and especially women. To ensure social development for poorers, it focuses on some additional approaches, such ascommunity driven development that gives control over planning decision of local stakeholders, gender equality for decision making and economic opportunities reducing gender based violence, strenthening girls education , reproductive health, social resilience, climate change and so on [75].

Garry Jacobs and Harlan Cleveland[22] jointly said that once upon a time, development was perceived in terms of a set of desirable results such as high incomes, longer life expectancy, lower infant mortality and more education etc. Recently, it has been emphasised on and shifted to the enabling conditions, strategies and public policies for achieving the new aspirations of society such as peace, good governance and democracy, social freedom, equal access to resources, gender equality, education and technology etc.But still little attention has been placed on the underlying social process of development that determines how societies formulates, adopts, initiates and organizes, and few attempts have been made to formulate such a framework.Nowadays, the new formations of NGOs and civil society as the local independent and self determoned organizations other than governmental institutions, work to ensure the indicators of development for making a poverty free society.

Department of Social Development, Republic of South Africa supports social development as the services that facilitates human development and improves the quality of life. In purpose of ensuring these, it provides support to reduce poverty, vulnerability and the impact of HIV and AIDS through sustainable development programmes in collaboration with implementing agents such as state-funded institutions, Non-Governmental Organizations(NGOs), community-Based Organizations(CBOs) and Faith-Based Organizations(FBOs). The strategic plan of the department is informed by the ten point plan[66].

Amartya Sen [3]seen development as a freedom of humankind emphasizing on social development that will be ensured with the expension of GNP or of individual's incomes and of some other determinants, such as social and economic arrangements(for example, facilities of education and health care)as well as political and civil rights(For example, the liberty to participate in public discussion and security). He said development requires the removal of major sources of unfreedom, poverty as well as tyranny, poor economic opportunities as well as systematic social deprivation, neglect of public facilities as well as intolerance 
or overactivity of repressive state.

Raj Hans[26]said development is a reaction of economic development at a large i.e. it is a part of the changes which occurs in society. These include changes which occur on account of demand, population structure and composition, changes in tastes and temperaments of the consumers, producers and institutions etc. Similarly, the changes can be due to discovery of additional resources, new trends in capital formation and productive resources, increase in labor and managerial efficiency etc. According to him, development should be achieved through some process and planned actions such as removing of poverty, illiteracy, raising living standard of the people, reducing income gap, eradicating social evils, food self sufficiency etc.

United Nations Research Institute for Social Development (UNRISD)has developed certain indicators of development, catagorised as economic, social and demographic under the economic category fall growth rates of GNP and GDP, population and agriculture as percentage of total area. Under the category of social and demographic fall infant mortality rate, expectation of life birth, doctor participant ratio, crude birth rate, caloric consumption per capita, protein consumption per capita, literacy percentage in the society, housing facilities available and newspapers in circulation per thousand of population as well as number of telephones per thousand population[74].

United Nations Development Programm(UNDP), as the main concerning body in development sector that globally works since 1966 with people at all levels of society to help in promoting and enhancing their socio-economic conditions. To ensure the quality life of backward people in the world, UNDP focuses on the areas such as poverty reduction, democratic governance, crisis prevention and recovery, environment and energy, HIV/AIDS, women's empowerment, and capacity development [73].

At last but not to the least, the above variables are being considered as the basis of social development and NGOs' contribution to these things are evaluated in this study according to the pattern of organizations.

\section{The Emergence of NGOs}

It is called global associational revolution, to describe the phenomenal growth and expension of Non-Government Organizations (NGOs) in the contemporary conception of development.This kind of revolution was started firstly in Britain under the name of private voluntary organizations concerned mainly in aid.For instance, Save the Children Fund was established as long as 1919, and the Oxford Committee for Famine Relief(OXFAM)in 1947 [32].Basically,this term as "International Non-Governmental Organization" had been used in the UN charter in the year of 1947[44]. Therefore, it has been documented that from the end of the WW-II till to the beginning of the twenty-first century, the number of active NGOs has been increasing fastly for launching humanitarian actions whole over the world as shown in Figure 1[72].In Bangladesh perspective, many researchers consider the development of NGOs started with the inception of British rule in this subcontinent. But in Pakistan period,the development of civil society in Bangladesh is originally growth.

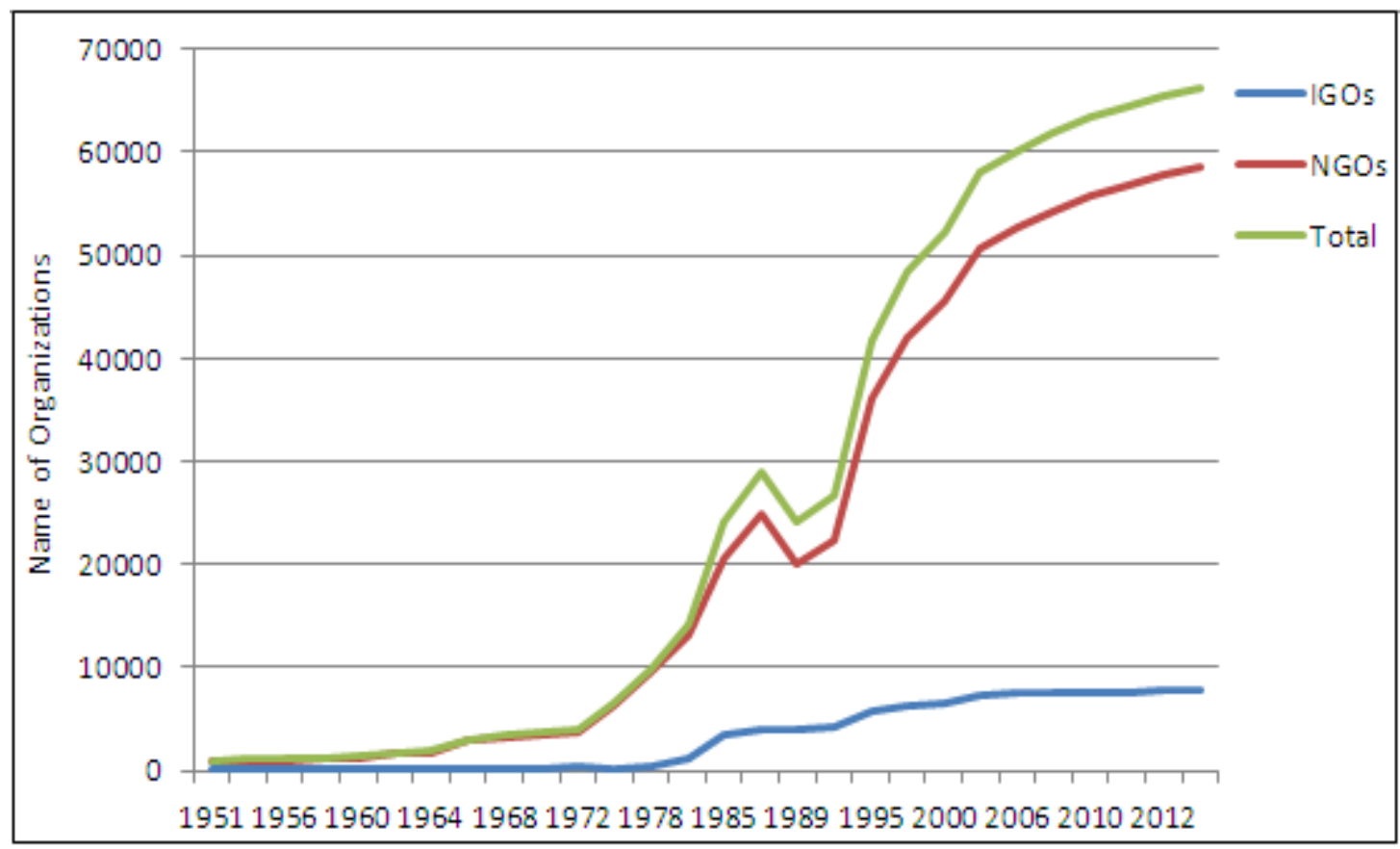

Source: www.uia.org

Figure 1. The Number of Active NGOs is Increasing Fastly for Launching Humanitarian Actions 


\section{NGOs and Civil Society: Meaning and Relationship}

It was believed that development is largely a task of the government but in a time being, especially in the twentieth century, a great dissatisfaction appeared with central economic system and government because of its unplanned and corrupted actions. As an alternative way of development, people become interested in non-profit private sector at a large extent namely civil society. This is neither an organ of government nor a part of profit making organizations. More explicitly, we can say that society has three main parts mobilizing their resources in three ways. As the government, the business sector, and the private non-profit sector (NGOs and Civil Society). The last one is being regarded as the third sector [40] or voluntary sector of a country which mobilizes its resources with sharing values and commitment to mass people especially in grass root levels [47].Most of the literature on civil society and poverty reduction process focuses mainly on NGOs and sometimes uses the terms "NGOs and civil society" interchangeably [66]. It has been argued that there is a strong tendency for NGOs to simply divorce themselves from civil society in practice. In fact civil society embraces NGOs and also includes faith-based organizations, religious communities, informal groups, co-operations, recreational and cultural organizations as well as academics and the media. So, it is postulated that NGOs are the organizations within the domain of civil society [59].

The organization of civil society basically is based on two things. As in one hand, organization's operating for the benefits of others. Firstly, one includes various kinds of indigenous community group, cooperatives, religious societies, trade organizations and professional associations; those belonged together for helping their members. On the other hand, it also includes local philanthropic institutions, NGOs i.e. private voluntary welfare and development organizations and non-profit companies; those embrace the tasks to fulfill the demand of poor as others. In this sense, we can say that NGO is a main organ of the civil society which has been coupled to ensure development of backward people. If we look at the organizations of civil society in Bangladesh, many types of NGOs' work as a civil society for social development- Adhunik trying to reduce smoking, Mohila Samity trying to improve the empowerment of women, Sandhani trying to provide blood to needed people, the Grameen Bank, BRAC, PROSHOKA, ASA trying to provide credit on low interest without taking mortgage or collateral security [53].

\section{Propagation of NGOs in Bangladesh}

In Bangladesh, NGO is an association of persons formed through the personal initiatives of a few committed persons dedicated to design, study, and implementation of development projects at the grass-root levels [1]. But it refers to all organizations and institutions that are registered with the government under the Voluntary Social Welfare Agencies(Registration and Control) Ordinance of 1962 and the Foreign Donation (Voluntary Activities) Regulation Ordinance of 1978 whatever their role and function may be[44].

At the present, NGO sectors in Bangladesh have been rapidly increasing in size, scope, membership, finances and pressure within the area of international development. It is estimated that there are 19000 NGOs are working in Bangladesh [44] which are mostly established for achieving the Millennium Development Goals as motto. Although NGOs started their activity as a relief and rehabilitation firstly, but now considered as one of the most sophisticated nation wide developmental networks in Bangladesh[2,5].Recently, NGOs have played an essential part of the proper functioning in the development sectors, widely praised helping to initiate and enhancing the strengthen comprehensive and objective dialogue between government and the state. In the years after independence, people exhorted to take the initiative with respect to social transformation; now the expectation is that NGOs will perform the same role. In the fields of education, health, providing drinking water, organizing forest management groups, or thrift societies for working women, NGOs are supposed to take the lead[12]. It is noted that in past two decades, more than 20,393 projects have been approved and successfully implemented in Bangladesh and its monetary value is USD 7,609,659,783.87 as shown in table 1[69]. 
Table 1. Flow of Foreign Grant Fund Through NGOs since FY 1990-1991 upto FY 2013-2014

\author{
NGO Affairs Bureau \\ Prime Minister's Office \\ Computer Section \\ FLOW OF FOREIGN GRANT FUND THROUGH \\ NGO AFFAIRS BUREAU: AT A GLANCE
}

Since inception and upto September, 2013

\begin{tabular}{|c|c|c|c|c|c|c|}
\hline $\begin{array}{l}\text { PERIOD } \\
\text { (July - June) }\end{array}$ & $\begin{array}{l}\text { APPROVED } \\
\text { PROJECTS } \\
\text { (NUMBER) }\end{array}$ & COMMITMENT & RELEASED & $\begin{array}{c}\text { CUMULATIVE AMOUNT } \\
\text { APFROVED } \\
\text { [TAKA] }\end{array}$ & $\begin{array}{l}\text { CUMULATIVE AMOUNT } \\
\text { RELEASED } \\
\text { [TAKA] }\end{array}$ & $\begin{array}{l}\text { CUMULATIVE } \\
\text { APPROVED } \\
\text { PROJECTS } \\
\text { [NUMAFR] }\end{array}$ \\
\hline $\begin{array}{l}\text { 8rought Forward } \\
\text { Upto June' } 90 \text { ) }\end{array}$ & 8 & \begin{tabular}{r|}
$14,892,279.00$ \\
$372,306,98$
\end{tabular} & $\begin{array}{r}217,169,685,00 \\
5,429,242,13\end{array}$ & $\begin{array}{r}14,892,279,00 \\
372,306,98\end{array}$ & $\begin{array}{c}217169685.00 \\
5.429 .242 .13\end{array}$ & 8 \\
\hline F.Y. 1990-91 & 464 & $\begin{array}{r}6,341,680,229.33 \\
5 \quad 158,542,005.73 \\
\end{array}$ & $\begin{array}{r}4,264,080,522.19 \\
5 \quad 106,602,013.05\end{array}$ & $\begin{array}{r}6,356,572,508.33 \\
158,914,312.71\end{array}$ & \begin{tabular}{|r|}
$4,481,250,207.19$ \\
$112,031,255.18$
\end{tabular} & $47 / 2$ \\
\hline F.Y. 1991-92 & 549 & \begin{tabular}{|r}
$11,484,379,404.67$ \\
s $287,109,485,12$ \\
\end{tabular} & \begin{tabular}{|r}
$4,865,522,844,98$ \\
s $121,638,071,12$ \\
\end{tabular} & $\begin{array}{r}17,840,951,913.00 \\
446,023,797.83 \\
\end{array}$ & $\begin{array}{r}9,346,773,052.17 \\
233,669,326.30 \\
\end{array}$ & 1021 \\
\hline F.Y. 1992-93 & 626 & $\begin{array}{r}15,995,368,116.77 \\
\text { s } 399,884,202.92\end{array}$ & \begin{tabular}{|r}
$7,828,230,680.78$ \\
s $\quad 195,705,767.02$
\end{tabular} & $\begin{array}{r}33,836,320,029.77 \\
845,908,000.74\end{array}$ & $\begin{array}{r}17,175,003,732.95 \\
429,375,093.32\end{array}$ & 1647 \\
\hline F.Y. 1993-94 & 581 & $\begin{array}{r}12,600,960,786.60 \\
\text { s } 315,024,019.67\end{array}$ & \begin{tabular}{|r}
$6,840,362,530.43$ \\
s $\quad 171,009,063.26$ \\
\end{tabular} & $\begin{array}{r}46,437,280,816.37 \\
1,160,932,020.41 \\
\end{array}$ & $\begin{array}{r}24,015,366,263.38 \\
600,384,156.58\end{array}$ & 2228 \\
\hline Y. 1994-95 & 579 & \begin{tabular}{|r|}
$17,627,496,279.39$ \\
s $440,687,406.98$
\end{tabular} & \begin{tabular}{|r}
$8,380,189,748.61$ \\
s $209.504,743.72$ \\
\end{tabular} & $\begin{array}{r}64,064,777,095.76 \\
1,601,619,427.39 \\
\end{array}$ & $\begin{array}{r}32,395,556,011.99 \\
809,888,900.30 \\
\end{array}$ & 2807 \\
\hline Y. 1995-96 & 702 & \begin{tabular}{|r}
$14,672,397,699.40$ \\
s $366,809,942,49$
\end{tabular} & \begin{tabular}{|r|r|} 
& $10,372,077,588.53$ \\
s $259,301,939.71$
\end{tabular} & $\begin{array}{r}78,737,174,795.16 \\
1,968,429,369.88\end{array}$ & $\begin{array}{r}42,767,633,600.52 \\
1,069,190,840.01\end{array}$ & 3509 \\
\hline F.Y.1996-97 & 746 & $\begin{array}{cc} & 10,259,187,684.80 \\
\$ & 246,496,580.61\end{array}$ & \begin{tabular}{|c}
$10,410,941,131.80$ \\
\$ $250,142,747.04$
\end{tabular} & $\begin{array}{r}88,996,362,479.96 \\
2,138,307,604.04\end{array}$ & \begin{tabular}{r|}
$53,178,574,732.32$ \\
$1,277,716,836.43$
\end{tabular} & 4255 \\
\hline F.Y.1997-98 & 705 & \begin{tabular}{|c} 
\\
\\
$\$$
\end{tabular} & $\begin{array}{cc} & 9,360,719,019.00 \\
\$ & 206,866,718.65\end{array}$ & $\begin{array}{r}97,521,022,708.96 \\
2,155,160,722.85\end{array}$ & $\begin{array}{r}62,539,293,751,32 \\
1,382,083,839.81 \\
\end{array}$ & 4960 \\
\hline F.Y.1998-99 & 1045 & $\begin{array}{r}18,247,739,167.00 \\
\text { s } 380,161,232.65\end{array}$ & \begin{tabular}{|c}
$13,128,024,641.00$ \\
s $273,500,513.35$ \\
\end{tabular} & $\begin{array}{r}115,768,761,875.96 \\
\text { s } 2.411,849,205.75\end{array}$ & $\begin{array}{r}75,667,318,392.32 \\
1,576.402,466.51\end{array}$ & 6005 \\
\hline$\overline{Y 1999-2000}$ & 776 & \begin{tabular}{|r|}
$13,897,601,871.00$ \\
s $257,362,997.61$
\end{tabular} & $\begin{array}{r}9,846,902,185.00 \\
\text { s } 182,350,040.46\end{array}$ & $\begin{array}{rr} & 129,666,363,746.96 \\
\text { \$ } & 2,401,228,958.28 \\
\end{array}$ & $\begin{array}{r}85,514,220,577.32 \\
1,583,596,677,36\end{array}$ & 6781 \\
\hline $72000-2001$ & 868 & $\begin{array}{r}19,414,341,9433.00 \\
\text { s } 359,524,850.80\end{array}$ & $\begin{array}{r}13,548,423,300,00 \\
\text { s } 250,896,727.78\end{array}$ & $\begin{array}{r}149,080,705,689.96 \\
\text { s } \quad 2,760,753,809.07\end{array}$ & $\begin{array}{r}99,062,643,877.32 \\
1,834,493,405.14\end{array}$ & 7649 \\
\hline Y2001-2002 & 746 & $\begin{array}{r}17,022,431,138,00 \\
\$ \quad 298,639,142.77\end{array}$ & $\begin{array}{r}11,872,074,573,00 \\
\$ \quad 208,282,010.05\end{array}$ & $\begin{array}{r}166,103,136,827,96 \\
\$ \quad 2,914,090,119.79\end{array}$ & \begin{tabular}{|r|r|} 
& $110,934,718,450.32$ \\
$\$$ & $1,946,223,130.71$
\end{tabular} & 8395 \\
\hline $72002-2003$ & 794 & $\begin{array}{l}15,692,909,817,32 \\
\text { s } \quad 275,314,207.32\end{array}$ & $\begin{array}{r}15,939,712,884.47 \\
\mathrm{~s} \quad 279.644,085.69\end{array}$ & $\begin{array}{r}181,796,046,645.28 \\
5 \quad 3,189,404,327.11\end{array}$ & \begin{tabular}{|r}
$126,874,431,334.79$ \\
s $2,225,867,216.40$
\end{tabular} & 9189 \\
\hline $2003-2004$ & 939 & $\begin{array}{r}28,219,719,991,48 \\
\text { s } 495,082,806.87\end{array}$ & $\begin{array}{r}17,845,182,750,96 \\
\text { s } 313,073,381,60\end{array}$ & $\begin{array}{r}210,015,766,636.76 \\
\$ \\
3,684,487,133.98\end{array}$ & $\begin{array}{rr} & 144,719,614,085.75 \\
\$ & 2,538,940,598.00\end{array}$ & 10128 \\
\hline $22004-2005$ & 1193 & \begin{tabular}{|r|}
$18,204,270,908.58$ \\
$\$ \quad 319,373,173.83$
\end{tabular} & $\begin{array}{r}15,619,009,844.39 \\
\$ \quad 274,017,716.57\end{array}$ & $\begin{array}{r}228,220,037,545.34 \\
\$ \quad 4,003,860,307.81\end{array}$ & $\begin{array}{rr} & 160,338,623,930.14 \\
\$ & 2,812,958,314.56\end{array}$ & 11321 \\
\hline $22005-2006$ & 930 & $\mathrm{~s}^{26,037,195,322.25}$ & $\begin{array}{l}19,809,060,637.59 \\
\mathrm{~s} \quad 347,527,379.61\end{array}$ & $\begin{array}{r}254,257,232,867.59 \\
\text { s } \\
4,460,653,208.20\end{array}$ & 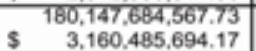 & 12251 \\
\hline $2006-2007$ & 908 & $\begin{array}{r}35,510,117,002.59 \\
s \quad 507,287,385.75\end{array}$ & $\mathrm{~s}^{22,582,881,027.53}$ & $\begin{array}{r}289,767,349,870.18 \\
5 \quad 4,139,533,569.57\end{array}$ & $\begin{array}{l}202,730,565,595.26 \\
5 \quad 2,896,150,937.08\end{array}$ & 13159 \\
\hline $22007-2008$ & 1462 & $\begin{array}{r}30,950,648,293,06 \\
s \quad 442,152,118.47 \\
\end{array}$ & $\begin{array}{r}36,617,993,216.62 \\
\$ \quad 523,114,188.81 \\
\end{array}$ & $\begin{array}{r}320,717,998,163.24 \\
5 \quad 4,581,685,688.05\end{array}$ & 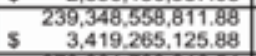 & 14621 \\
\hline $2008-2009$ & 1042 & $\begin{array}{r}28,981,629,779.89 \\
\$ \quad 414,023,282.57\end{array}$ & $\begin{array}{r}34,033,174,404,66 \\
\$ \quad 486,188,205.78\end{array}$ & $\begin{array}{r}349,699,627,943,13 \\
\$ \quad 4,995,708,970.62\end{array}$ & \begin{tabular}{|r}
$273,381,733,216.54$ \\
$\$ \quad 3,905,453,331,66$
\end{tabular} & 15663 \\
\hline F.Y2009-2010 & $117 / 2$ & $\begin{array}{r}47,696,609,161,00 \\
\$ \quad 681,380,130,87\end{array}$ & $\begin{array}{r}36,122,337,950.00 \\
\$ \quad 516,033,399.29\end{array}$ & $\begin{array}{r}397,396,237,104.13 \\
5,677,089,101,49\end{array}$ & \begin{tabular}{|r}
$09,504,071,166.54$ \\
\\
$4,421,486,730.95$
\end{tabular} & 16835 \\
\hline F.Y2010-2011 & 1120 & \begin{tabular}{|r|}
$50,791,187,989.00$ \\
$\$ \quad 725,588,399.84$
\end{tabular} & $\begin{array}{r}46,125,631,311,50 \\
\$ \quad 658,937,590,16\end{array}$ & $\begin{array}{r}448,187,425,093,13 \\
\$ \quad 6,402,677,501,33\end{array}$ & \begin{tabular}{|r}
$355,629,702,478.04$ \\
$\$ \quad 5,080,424,321,11$
\end{tabular} & 17955 \\
\hline F.Y2011-2012 & 1077 & \begin{tabular}{|r}
$70,447,029,441.58$ \\
$\$ \quad 939,293,725.89$
\end{tabular} & \begin{tabular}{|r}
$43,473,317,648.48$ \\
$5 \quad 579,644,235.31$
\end{tabular} & $\begin{array}{r}518,634,454,534.71 \\
\text { s } \quad 6,915,126,060.46\end{array}$ & 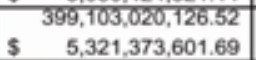 & 19032 \\
\hline F.Y2012-2013 & 1048 & $\begin{array}{r}47,9806,952,535.26 \\
\$ \quad 639,826,033.80\end{array}$ & $\begin{array}{r}50,813,584,722.85 \\
\$ \quad 677,514,196,30\end{array}$ & $\begin{array}{r}566,621,407,069.97 \\
7,554,952,094.27\end{array}$ & $\begin{array}{r}449,916,584,849,37 \\
5,998,887,797,99\end{array}$ & 20080 \\
\hline $\begin{array}{l}\text { F.Y2013-2014 } \\
\text { (Upto Sep'13) }\end{array}$ & 313 & $\begin{array}{r}19,3222,396,288.00 \\
\$ \quad 250,940,211.53 \\
\end{array}$ & 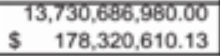 & $\begin{array}{r}585,943,803,357.97 \\
\$ \quad 7,609,659,783.87 \\
\end{array}$ & \begin{tabular}{rr|} 
& $463,647,271,829.37$ \\
$\$$ & $6,021,393,140.64$ \\
\end{tabular} & 20393 \\
\hline
\end{tabular}

Source: www.ngoab.gov.bd

The importance of the civil society organizations (CSOs) in the last three decades is increasing with the expansion of globalization, neo-liberalism and participative democracy. In the economic market forces, civil society is a new actor to provide social and economic welfare services. In the modern society, civil society can be considered as a momentous institution which provides social aids with philanthropic sentiments [49]. In Bangladesh Non-Government Organization play an important role in the area of micro-finance, promotion of income generating activities, health and education services, community mobilization, right awareness, disaster management operation [8]. The leading NGOs that work in Bangladesh in humanitarian crisis and social development, as follows-
BRAC: BRAC, though it was emerged as a relief and rehabilitation organization in 1972 by F.H. Abed in a very limited scope and operation but in once upon a time, has turned into the largest developmental organization in Bangladesheven in the world creating opportunity for poor. Its main prioritsed operation focuses on women, empowerment for grassroot people, health , education,microfinance, social awareness etc. BRAC's pre-primary education programme coverage 32900 children and its non formal primary school coverage almost 610,000 students.It is working in reducing dropout students and enhance their education programme in very distant and remote area of Bangladesh. BRAC successfully reduce maternal mortality in10 districts and successful in 
performance of detecting $(78 \%)$ and recovering $(92 \%)$ Tuberculosis in its working area.It is also working on climate change and giving necessary logistic support to people to adopt with environment in coastal areas[16].Nowadays, BRAC Iinternational is working outside of Bangladesh innine other countries of Asia, Africa and the Caribbean, where it is providing services about 138 million people. The future plan of the BRAC is designed as keeping the MDGs in mind, having a more integrated development approach in selected upazillas.Taking coordinated initiatives for Dhaka slum dwellers and street children and incorporating information technology in development activities to make it more efficient and cost effective [68].

Proshika: It is also a one of the largest NGOs in Bangladesh, started in a few villages of Dhaka and Comilla districts in 1975, but it formally ran in 1976. Proshika now coverage 21,272 villages and 2,380 urban slums in 55 districts. PROSHIKA's objectives are: (i) structural poverty alleviation; (ii) environmental protection and regeneration; (iii) improvement in women's status; (iv) increasing people's participation in public institutions; and (v) enhancing people's capacity to gain and exercise democratic and human rights".In the micro credit pogramme, Proshika disbursed loans Tk. 45,039 million (4,504 crore) to 6.50 million (65.02 lakh) group members and12.33 million (1.23 crore) employments self-employments created[17].

Grameen Bank:The Grameen Bank, initiated by Muhammad Yunus, is a Noble Peace Prize-winning microfinance organization and community development bank founded in Bangladesh. It is a very familiar to all, especially in the people of grass root levels, because of its keeping contribution in rural and backward areas. In 1976, Dr. Muhammad Yunus implemented a research project for giving opportunity poor people to access in loan. For making a successful commence of loan to poor people, it was authorized in 1983 by Bangladesh national legislation [76] with taking responsibility to provide credit to poorer without taking any kinds of collateral security.On that time, its initiator met with agricultural labor, supervised and gave guidelines about irrigation system for better crops. Preliminarily, he gathered farmers and formed Village Organization (VO) with the purpose of cooperating one another and depositing money for savings for future investment. A member of household who owns less than 0.5 acre of cultivable land or assets, the value of which does not exceed 1 acre, is eligible to take loans from the bank. Firstly, loans were sanctioned for non-agricultural activities such as milch cow, paddy husking, cattle fattening, seasonal crop trading and grocery shop operating. Loans only were given to women because of ensuring womens' empowerment. Day by day, it increases the amount and size of loan disbursement. Women are being more encouraged to issue loan for enterprises. By 1993, the cumulative loan disbursement was tk. 30.740 million of which women shared tk.26.535 million [39]. In 2010, its paid revenue was 176.67 million USD, net income was 10.76 million USD, and total number of employees is 22,249 in 2011[76].

As a symbol of successful and prospective operation, Grameen Bank won a World Habitat Award for its "Low-cost Housing Program" and in 2006, the bank and Muhammad Yunus were jointly awarded the Noble Peace Prize for establishing peace environment by reducing poverty in Bangladesh.

ASA : It was established in 1978 with a view to ascertain a poverty free society by materializing a mission as to support and strengthen the economy at the bottom of the socio-economic pyramid by ensuring access to financial services for the poor, marginalized and disadvantaged people. Its main focus is on consciousness raising, group development and training among the rural poor. Services, offered by ASA, divided into two categories, as financial and non-financial. Its largest program is microfinance with major emphasis on women empowerment. The total number of borrowers under the micro credit program is 4,165,037 of those female borrower is more than 89 percent [6]. ASA has set a trend of periodic impact assessment of its program in every 2 to 4 years since 1999 to identify the problems at stake, assess the work strategy adopted for achieving objectives. In 2013, as a continuation of its assessment process, it has been seen that 97 percent respondents of total study have been able to increase their business capital and monthly income through Income Generating Activities (IGA) and family asset increased of 83 percent respondents [7].

CARE Bangladesh: CARE Bangladesh as another largest international NGO, has been working in Bangladesh for 60 years. Its operation was started for seeking a poverty free world in where hope, tolerance and highest level of social justice will be existed along with zero level of tolerance to gender discrimination. CARE Bangladesh incepted its journey with core values of respect, integrity, commitment to serve, excellence and diversity. The strategic planning framework of CARE Bangladesh is highlighted with the impact vision of the most socially, economically and politically marginalized women should be empowered by making them financially solvent[65].

\section{Functions of NGOs: A Journey to Promote Social Development in Bangladesh}

NGOs make efforts to remove the structural barriers of poverty through initiating institutional changes and building the organizations of the poor. But from their experience they recognize that with a view to making these organizations effective, the myth of mental inhibition of the poor, generated by a sense of helplessness, inertia, fatalism and passive acceptance of social injustice, was to be exploded. With a view to breaking the Poor's mental barriers, the NGOs choose a process of maximum participation in community development. The NGOs attempt to bring about 
changes in attitudes of the poor and also change their capabilities to find out and examine the causes of exploitation and dependence, through this processes.In addition,NGOs initiate 'bottom-up approach' in contrast to 'top-down approach' as the traditional practice in development[21]. The former focuses on community organizing, grass-roots movements, local participation, and local decision making. The strength of this approach lies in its ability to encourage locally tailored responses to meet local needs[18] that are evaded by government's initiation. At a large extant, NGOs keep contribution to the following sectors as the means of ensuring the betterment of backward people as well as country.

Microcredit: The micro credit scheme, provided by NGOs, has been praised for its success in poverty reduction[8]. This is not only giving loans in small scale to women for income-generating activities but also reducing dependency on the usual money lender. Besides, microfinance loans make able families to enroll their children in primary school and to avoid pulling them out of school $[35,25]$. It is true that poor people with credit worthy have access to quality basic social services i.e., quality education, quality health care, water and sanitation services which lead them to maintain standard of living[40].NGOs in Bangladesh are come forward to giving credit support for the poor and people in distant areas. Poor people are unable to fulfill the condition of security at traditional banking system because they have little property or no private property. The microcredit is the only financial system initiated by NGOs that provides loan to the poor or even to the hardcore poor people without taking any mortgage or collateral security $[64,16]$.A majority number of NGOs are working in this sector including BRAC, GB, ASA, CCDB etc with high increasing rate day by day. As, GBs disbursement of loan was almost eight crore and in 1997 it has been increased more than nine crore.On the otherhand, there is a dramatic growthness also is seen within this short period as 8 lac in 1990 and it was more than 60 lac in 1997. More than 90 percent of this disbursement of credit would sanctioned for landless people[40,5].

The aims of microcredit policy is to establish social welfare such as to promote credit as a human rights, aimed towards the poor particularly poor women, It is based on 'trust', not on legal procedures and system, it is offered to create self-employment, income-generating activities and housing for the poor as opposed to consumption. It was initiated as a challenge to conventional banking which rejects the poor by classifying them as 'not creditworthy'. It provides service on the door-step of the poor based on the principle that the people should not go to the bank rather bank should go to people. It gives high priority to building social capital $[28,34]$.

Education: In order to eradicating illiteracy, the NGOs have been working on children's education particularly in girls' education. The largest NGOs in our country, BRAC has started satellite school system based on informal education policy. From the beginning till to the date, BRAC has been providing basic education almost 10 million students in Bangladesh. In 2012, total number of students, passed from BRAC's primary schools at PSC examination is 206336 [10] those are come from fully marginalized family. An international organization, CARE Bangladesh facilitated a project on functional education targeting 1000 working children of certain age primarily in the location of Tongi and Gazipur, to develop their human capital providing technical competencies and marketable skills [13].

Health: In a collective effort to make public health a frontline agenda, United Nations (UN) has incorporated multiple health components in its Millennium Development Goals (MDGs), emphasizing on improving maternal health, reducing neonatal mortality, and combating HIV and other communicable diseases following the UN Millennium Summit, 2000. Aligned with this global concern, BRAC has initiated and is implementing several programmes under the umbrella of its health programme in Bangladesh, to address health issues and to achieve the MDGs by 2015.For instant, TB treatment success rate is 93 percent. There is also a great success in malaria prevalence, as in 2007,549 people were affected by Malaria per 1,00,000 . This number has been reduced in 2012 as 271 [10].ASA as the another largest NGO of Bangladesh, also launches a massive campaign on health issue conducted by 3000 branches. It is estimated that one million people were provided with relevant health information in 2012[6].BRAC's WASH (Water, Sanitation, and Hygiene) program is another hallmark initiative in health sector. Under this program extreme poorer get financial cooperation in construction sanitary latrine and also obtain awareness about sanitation system. So far, the efforts of WASH Program have changed 2.5 million latrines into hygienic latrines, mobilized 1.6 million families to independently construct sanitary latrines, established 2,350 rural sanitation centers, installed sanitary latrines for girls in 4,200 secondary schools, offered grants to 800,000 ultra poor families, and facilitated loans to 180,000 poor families. In addition to these accomplishments, the program has also reached millions with hygiene education [70].

The Lancet documented in 2013 that Bangladesh achieved a great success in health especially in the improvements in the survival of infants and children under 5 years of age, life expectancy, immunization coverage and tuberculosis, even in the South Asian countries despite of being poorest country in the world. The rate of women dying in children has dropped by 75 percent since 1980 in Bangladesh, while infant mortality has more halved since 1990, life expectancy has increased to 68.30 years. More researchers and commentators regarded this as "exceptional health progress", "health revolution" etc. Amartya Sen pointed on four factors for achieving this success. As an emphasis on reducing gender discrimination, public-private entrepreneurship, community based activities, and powerful initiative against natural calamities. In these cases, all successive events have been occurred by dint of NGO's operation in grassroot levels from large initiatives like BRAC and Grameen Bank to 
smaller organization [60].The figure 2 [71]shows that because of NGO's intervention, the gap about the probability of survival between non poor non member and poor member is very low whereas gap between poor non member and non poor member is very high.

\section{Promotion of women status/Women Empowerment}

Of the total population of Bangladesh around $49 \%$ are women. As this kind of sex forms the half of our population almost; therefore, it is hardly possible to achieve the comprehensive, sustainable, social and economic development without the participation of women in all spheres of life[9].So, it is well mentioned that women should have equal rights and privileges in all sectors of society. It is also postulated in the constitution of Bangladesh,article 28 [24]. Over the years, NGOs, as the development partners of government,are working towards women empowerment and implementing a series of development intervention for eliminationg gender discrimination.As the continuation of initiatives, NGOs have arranged many income generating activities viz. apiculture, silk production embroidery, fishnet matching, poultry and livestock to increase the socio economic condition of women. Various programmes related to womens' empowerment, promote vegetable gardening by ensuring the participation of women [55].This is very noteworthy that microfinance program also promotes women status and empowerment both in domestic and outside of family [45]. In addition, NGOs are verily engaged in integration of development programes as economic development, consciousness-raising, awareness building and organizing women to reduce their powerlessness that lead to empowerment[58].To promote women status in Bangladesh, domestic violence should be tackled in society. There is a large number of NGOs those are working on this issue. In 2012, CARE Bangladesh provided a list of 81 developmental organizations (NGOs and CBOs) including
BRAC, CARE-Bangladesh, Concern Worldwide, Hitaishi Bangladesh, Manusher Jonno, Mohila Porishad, Oxfam, The Royal Dutch Embassy and Steps Towards Development have been launching project on issues pertaining to violence against women, either through direct services or advocacy [37].

Raising Awareness: NGOs are initiating democratization processes [48] aiming at restructuring the existing power-relations through the empowerment of the rural poor and development of their organization through a continuous process of education, awareness building and resource mobilization. Thus they organized poor for participating in the local decision-making process, such as, 'salish', local election and similar activities of village. NGOs and Civil society wants to ensure that citizens have the means to express their engages in dialogue with policy makers and influence policy making. Civil society organization demand accountability in the allocation and management of the public resource. In establishing good governance in Bangladesh, many NGOs such as Amnesty International, Transparency International Bangladesh, and Centre for Policy Dialogue are working as a watch dog of different servicesthat give guidance and awareness to government. Democracy watch is most well-known NGOs which performs electionand media monitoring activities regularly [38]

Access to Government Resources: Many NGOs have created the unconventional opportunity to use the khas land by introducing social forestation and group irrigations system for landless people usage. Particularly, NGOs are organizing the landless people, establishing village based nursery, assisting in social forestation and tree plantation, taking lease to khas land and dry riverbed to make use of shared fish culture [69, 42].

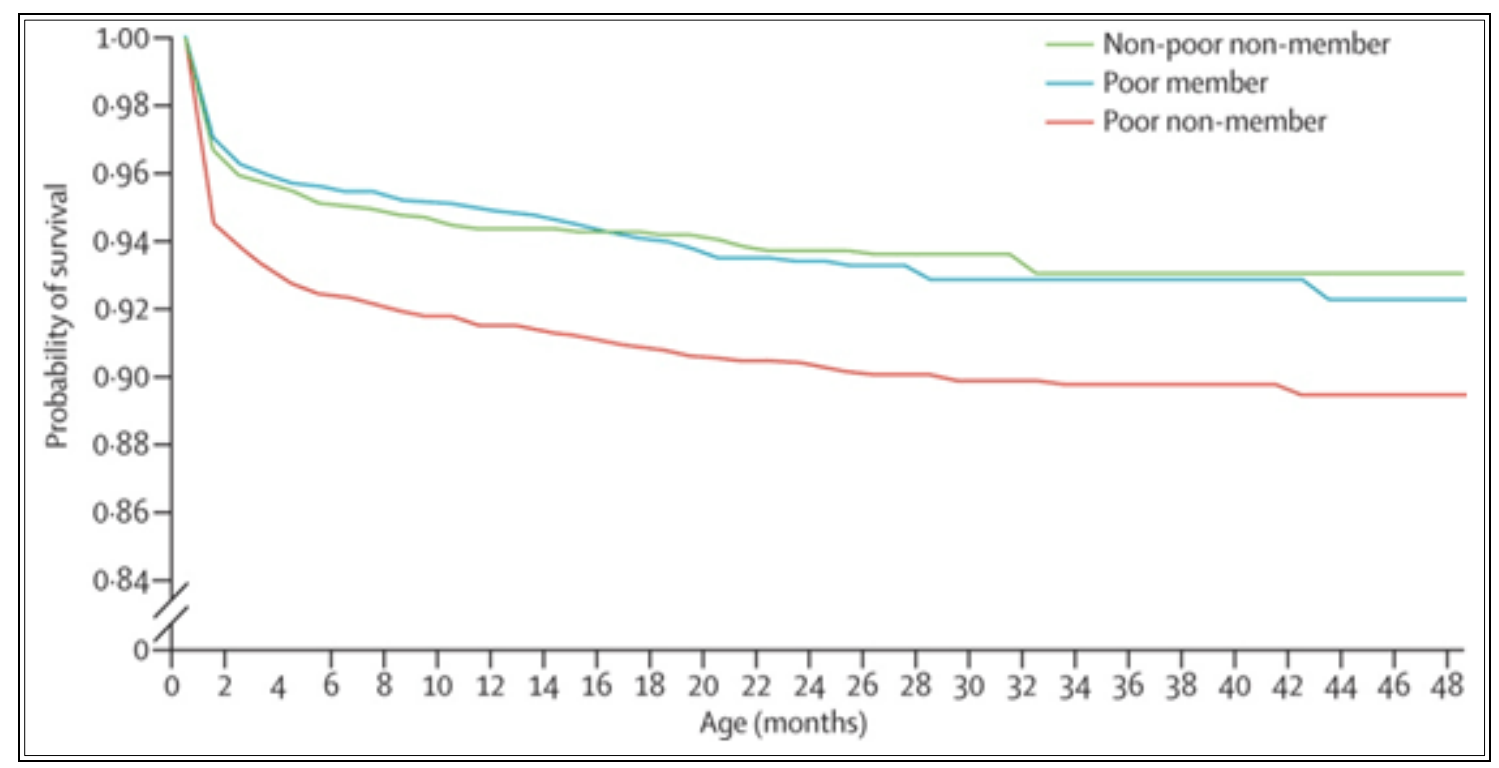

Figure 2.. the gap about the probability of survival between non poor non member,poor member and poor non member 
Environment: The major environmental problems in Bangladesh include deforestation, desertification arsenic problem and damage to the genetic and aquatic environment. The NGOs undertake various programs to contest deforestation and to improve the conditions of deforestation as well as in a forestation programs, improving sanitation facilities and ensuring supply of safe drinking water through distribution of water-sealed latrines and tube-wells among the beneficiaries [69].

Relief and Rehabilitation: At the time of natural disasters like flood, drought, famine, storm, contaminated diseases, the NGOs have been planning a momentous role in distributing relief and substantial help among the wounded people along with government and after disaster, and then they would also undertake different rehabilitation activities for the betterment of disaster affected people [69].

Employment Generation: NGOs are playing significant role to encourage the rural poor to participate in different economic activities and to increase their income through employment generation. They are now providing several methods, policy, and strategies to the development of rural areas. Begum [8] identified major contribution of employment generation to the poor. In order to operate NGOs activity, they provided employment in their own organization. Some large organizations launches very effective professional training for higher official and unemployed people that generate job facilities. On the other hand, they provide loans and management assistance to individuals, which create new employment opportunity. Currently the projects that are being conducted under the supervision and assistance of NGOs are Irrigation project for landless, Fishery in ponds (khash), Fishing in the coastal area, Weaving Equipment supplies for landless share cropper, Bee keeping,Small business, Rice and popcorn production, Sericulture Handicrafts i.e. earthen wares, wood and cane works, Developing nurseryetc[ 8].

Non-traditional agricultural extension and Food Security: Under taking the program of agriculture and food security, BRAC works with government to ensure food security by keeping direct contribution in producing, distributing and marketing quality seeds, conducting research to develop better varieties. In 2012, under share croppers development project, total borrowers was 2, 00,000 and more than 1, 50,000 farmers got training on their agricultural works as the extension of non-traditional agriculture [10]. Some NGOs undertake unique programs of technology involving innovative fertilizer usage and waste management. These activities are complemented by training of local people and a national advocacy campaign. Some NGOs are developing an extended system of appropriate technology transfer for homestead agriculture. The NGOs are not only arrange to teach appropriate technology for fruits, vegetables, fish and cooking but also transfer of suitable technology for family agriculture[8]. CARE-Bangladesh successfully introduced a project named "SHOUHARDO" as the ensurement of food security targeting Poor and Extreme Poor (PEP) households for the duration of five year action plan. The program operates in the land of coastal area and haor belt of Bangladesh funded by USAID and GoB with funding approximately 130 million. This is one of the world's largest non-emergency food security development programs so far now [14]. It is hopefully said that this initiative taken by CARE-Bangladesh, is a significant contributor to Bangladesh's poverty elimination activities.

Family planning: NGOs have made momentous contributions on family planning. Specifically, Bangladesh's national policies and NGOs include a highly developed outreach programmes that offers family planning services through a programme of direct education and distribution of contraceptives in the homes and motivational activities as well as reproductive health care and surgical services of rural women and urban slums in Bangladesh[69].

\section{Critical Evaluation of NGOs in Bangladesh}

NGOs and CSOs have been working for reducing humanitarian crisis and promoting democracy based on bottom-up and people-participatory approach, but this sector of state is not free of controversy and criticism. With the observation of policy and functions of NGOs, some critical evaluations have been appeared centred on their performance and actual effectiveness, issues of accountability and autonomy, commercialization and taking shelter of political figure for project procurement[43]. Moreover, NGOs functioning is fully dependent on external funding. To collect fund, NGOs' management body is compelled to maintain donor's policy though it can be a harmful both for society and administration. Therefore, it is postulated that the third sector loses their autonomy in such a way. They impose forcely donor's willingness on community that may not be adjusted with legal structure [54,50]. Sometimes, NGOs' activities are too clumsy to identify the actual poor people and also their providing social services do not reach to the actual vulnerable groups at all $[52,77,56]$.

The last three ruling parties in Bangladesh have exercised their power and established some rules, regulations and institutional means to secure their legal status, resource acquisition, economic management, and internal and external linkages, but the scope of NGOs in Bangladesh in relation to governmental activities has increased because of various domestic and international factors[27,62].

NGOs claimed that they are triumph in providing primary services and in poverty reeducation but the evidence shows that NGOs have hardly been able to improve the conditions of rural poverty or they cannot give the loan to extreme poor people [4].Many field observation has shown that especially in least developing countries like Bangladesh, allocation of money in providing health, education, housing will be undergone in vain and fully failure to resolve the deprivation of poor if empowerment of beneficiaries groups will not be conjucted with as the ending processes [19]. The nature of 
development agency staff should be modified and morally committed. Experience tells that after the end of project it is hardly seen the continuation of project i.e. no automation created.

NGOs have full autonomy to provide their services. Poor people have tiny capacity to bargain for services in the large size ofNGOs. This is the real circumstances that the poor borrowers in Bangladesh are increasingly dependent on large NGO such as Proshika, BRAC, Grameen Bank and so on[15].Their services are so poor and clumsy than their actual exposure. The micro credit pragramme of large NGOs separated the poor into receivers and non-receivers of credit[15].The members of NGOs create the unity within their members but not to share a common causes with those another member of NGOs[27].This act may disintegrate and weaken the political action pursued by the extreme poor specially landless poor people. Microcredit pogramme of NGOs can be considered as a commercial aspect of NGOs which contributes to the paralysis of social and political action [61] and sometimes no difference is found with general banking.

Many global forces played a vital function to empower NGOs in Bangladesh such as the expansion of NGOs in number and size, creation of their popular image, and recognition of their roles by the government have been reinforced by global forces which changes the power, configuration between the government and NGOs in Bangladesh[27].

NGOs have huge man power in local area, with this man power NGOs can influences the local and national politics. At present, BRAC is fully working in 68,408 villages in all districts of Bangladesh. It has 4.8 million group members, 4.2 million borrowers[67].This evidence support that NGOs have large networks in local areas and surprisingly large numbers of membership in whole Bangladesh and also imply that these NGOs have a strong rural support in comparison to the government[27].In Bangladesh, NGOs have more popular image than any other state agency because of not only providing basic literacy and skills but also enhance socio-political awareness[27] among poor people. BRAC, Proshika, and Grameen Bank have been launching extensive programs of non-formal education and some professional training for their members and commoners which affects positively the attitudes about NGOs and their activities[27].

The new policy agenda under the structural adjustment program, prescribed by donors such as the World Bank, the Asian Development Bank, and USAID, emphasizes a reduction in state intervention by adopting market-based strategies like privatization and expanding voluntary institutions like national and international NGOs [41].Under the structural adjustment policy in Bangladesh, Bangladeshi policy makers were influenced by neoliberal beliefs in market-led solutions, less state intervention, and a greater role for non-state actors have significantly expanded the importance of NGOs in this country.

Some of NGOs in Bangladesh have emerged as a quasi commercial activity and working like corporate bodies. Many NGOs broaden their networks in rural people those are regarded as the producers and consumers of the NGOs. Many NGOs are endeavored in activity that are not for creating employment or opportunity for the poor at all rather they makes huge profits only for own[64]. NGOs profit making activities have negative impacts on the growth of civil society and their transparency as a whole. Most of the NGOs in Bangladesh are dependent on the aid of foreign donor agency and their ideas[51].The major international aid agency and foreign donar agency including World Bank, International Monetary Fund, International Finance Corporation, Asian Development Bank, World Food Programme, and the UN Economic and Social Council are putting pressure on the governments of developing nations like Bangladesh to undertake NGOs shelter as a means of implementing of good governance, democratization, poverty elimination, rehabilitation. As a result, this sector has been recognized day by day as legitimate players in global politics. So these international organizations force the government of Bangladesh not to impose any strictness on those organizations [27].

In Bangladesh, many local NGOs are run with the partnership of well reputed foreign NGOs. These NGOs have increased their power and intervening in many internal affairs of Bangladesh. Many foreign NGOs such as Oxfam, World Vision, Caritas, Save the Children, Greenpeace, Amnesty International and Transparency International not only influence activities of local NGOs but also pressurize our government to execute their power. On the other hand, for controlling NGOs activities and ensuring their accountability to the state, Bangladesh government established a regulatory body as NGO Affairs Bureau in 1990 through its administrative order. The NGO Affairs Bureau provides one stop service to national and international NGOs those are registered under Foreign Donations(Voluntary Activities) Regulation Ordinance, 1978. In such a way, NGOs, not able to make transparent in operation, will loss their registered validity.For instant, NGO Affairs Bureau cancelled operation and registration of 500 NGOs as on 31st October, 2013 [69].

\section{Conclusions}

The discussion made so far clearly reveals that civil society and its one of the costituent elements NGO as the third sector of a country is the quite vital force of developmental factors in Bangladesh. The sector is working for ensuring socio-economic development of poor and hard core poor people those are treated as the very negligible and marginalized by other two sectors i.e state and business. These sectors work with political implications and profit maximization respectively whereas NGOs do for poors and women especially on the ground of no generation of profit. Bangladesh as the poor country and also overpopulated state on the one, and on the other its majority of population is 
suffering from poor health, malnutrition and economical wants that result social chaos, coercion and disorganization or crime.So humanitarian works are needed with emphasise on health, education, food production, social security, legal support rather than industrialization or manufacturing production. In this sense, NGOs in Bangladesh, started its journey of works for securing health, ensuring compulsory education and training for all, empowering women by giving loan facilities, establishing good governance and so on by targeting especial group of people. It is worth to state that BRAC, as the largest NGO of Bangladesh, keeps important and influential role in the aforesaid sectors. Once upon a time, BRAC was fully dependent on foreign aid to launch project. But at the present, it is almost self sufficient financially and in policy creation. The same thing also seen in the activities of Grameen Bank, Proshika, CCDB, ASA etc. Environmentally Bangladesh is the most vulnerable country of the world.Many NGOs take steps as the implementation and accomplishment of project related to resistance of climate change and loss of biodiversity, embankment in coastal and low land areas to keep sound Bangladesh with friendly environment.But it is also true that the projects carried on by local NGOs mostly financed and technically supported by donor agencies. In this case, some sort of restrictions and their(Donors) wills are being imposed on economical and political systems of Bangladesh that are not perfect for country's structure and in such this case NGOs work as their local syndicate only. However, this is certainly true that the economy of Bangladesh, especially from the very beginning of post liberation period, rigorously dependent on NGOs' finance and upon their plan of actions both directly and indirectly though their works are not beyond critical evaluations and give birth of doubtness in developmental thoughts and paradigms.

\section{REFERENCES}

[1] Abdul Hye, Hasnat (1996)Below the Line: Rural Poverty in Bangladesh, The University Press Limited, Dhaka.

[2] Ahsan,KamrulA.H.M(2005) Role of NGO's Micro-Credit Program in Poverty Reduction In Bangladesh: A Study on Some Selected NGOs, Pakistan Journal of Social Sciences 3(8):1053-1059.

[3] Amartya Sen (2012) Development as Freedom, Oxford University Press, Published in India.

[4] Andrew Heywood (2000)Key Concepts in Politics, Macmillan Press Ltd., London. ISBN 0-333-77095-1.

[5] Asaduzzaman.M et al. (1993)Growth and Development in Rural Bangladesh: A Critical Review, University Press Limited, Dhaka.ISBN 984-05-1217-X.

[6] ASA Brief Report 2012.

[7] ASA Annual Report 2012-2013

[8] Begum ,SyedaFeroza; Zaman, SawlatHilmi and Khan,
Mohammad Shahin (2004) Role of NGOs in Rural Poverty Eradication: A Bangladesh Observation. BRAC University Journal, vol. I, no. 1, 2004, pp. 13-22

[9] Barbara Southard(1996)The Women's Movement and Colonial Politics in Bengal, The University Press Limited, Dhaka-1000, Bangladesh.

[10] BRAC Annual Report 2012.

[11] Brian Doherty, Alexandra Plows and Derek Wall (2007) Environmental Direct Action in Manchester, Oxford and North Wals: A Protest Event Analysis, Environmental Politics, Vol-16, No.5, P. 805-825.

[12] B S Baviskar (2001) NGOs and Civil Society in India, The Arkleton Trust Lecture 2001, The Arkleton Trust, Enstone, Oxon OX7 4HH, ISBN: 0906724465.

[13] CARE- Bangladesh Annual Report(2009) Providing Bangladeshi Working Children with Functional Education and Marketable Skills Project.

[14] CARE-Bangladesh Annual Program Progress Report, 2012.

[15] Chowdhury, A.N. (1990) Let Grassroots Speak: Peoples' Participation, Self-help Groups and NGOs in Bangladesh. Dhaka University Press, Dhaka.

[16] Chowdhury, Abdul Muyeed et al. (2005) Building Governance for Fighting Poverty, http://research.brac.net, 129-139.

[17] Colin Ball, Leith L. Dunn (1995) Non-Governmental Organizations: Guidelines for Good Policy and Practice, Commonwealth Foundation.

[18] Chi, Chien-Hua (2004) NGOs and the Creation of the International Criminal Court, Department of Diplomacy, National Chengchi University, Taipei.http://nccur.lib.nccu.e du.tw

[19] Dawson, Elsa L, "Assessing the Impact : NGO's and Empowerment", in (Ed.) Afshar, Haleh, Womenand Employment : Illustrations from the Third World, Macmillan Press Ltd., Great Britain, 1998.

[20] Denzin,Norman k. and Lincoln, Yvonna S. (1994)Handbook of Qualitative Research, SAGE Publications, ISBN-10: 0803946791, ISBN-13: 978-0803946798.

[21] Diamond L; Juan JL, Seymour ML (1995) Politics in Developing Countries: Comparing Experiences with Democracy. Lynne RiennerPublications: Boulder, CO.

[22] Garry Jacobs and Harlan Cleveland (1999)Social Development Theory, retrieved from www.icpd.org/develop ment_theory/socialdevelopmenttheory.htm

[23] Gemmill, B et al. (2013) The Role of NGOs and Civil Society in Global EnvironmentalGovernance, http://www.env-net.or $\mathrm{g} / . . . /$ gemmill.

[24] Gender Statistics of Bangladesh 2008 (2009)Bangladesh Bureau of statistics, Planning Division, Ministry of Planning, Government of the People's Republic of Bangladesh; ISBN: 984-508-885-6. Pp.01-05.

[25] Haider, Sheikh KabirUddin(2011) Genesis And Growth Of The NGOs: Issues In Bangladesh Perspective International NGO Journal Vol. 6(11), Pp. 240-247, November 2011

[26] Hans Raj(1999)Fundamentals of Demography: Population 
Studies with Special Reference to India, Surjeet Publications, India.

[27] Haque, M. Shamsul(2002) The Changing Balance Of Power Between The Government And NGOs In Bangladesh.International Political Science Review / Revue Internationale De Science Politique, Vol.23, No. 4 (Oct., 2002), Pp. 411-435Published

[28] Huber E, Rueschmeyer D, Stephens JD. (1993) The Impact Of Economic Development On Democracy. Journal of Economic Perspectives 7(3):71-85.

[29] Human Development Report (2002)Deepening Democracy in a Fragmented World, UNDP,http://hdr.undp.org/en/reports/g lobal/hdr2002.

[30] Human Development Report (2013) The Rise of the South: Human Progress in a Diverse World, UNDP,http://hdr.undp. org/en/reports/global/hdr2013.

[31] Joseph, Stiglitz (2003)Globalization and Its Discontents, Penguin Books India Pvt. Ltd., 11 community Centre, Panchsheel Park, New Delhi, India.

[32] J. E. Goldthrop (1984) sociology of the third world : Disparity and Development, Cambridge University Press, UK.

[33] Jerry McBeath (2004) Environmental Politics in Industrialized Nations, Global Environmental Politics 4:4, Published by MIT Press.

[34] Krishna A (Ed.). 2001. Changing Policy And Practice From Below: Community Experiences In Poverty Reduction. United Nations DevelopmentProgramme: New York.

[35] Katy Glenn (2004)Educate Every Child: Microfinance and Universal Primary Education, http://www.microfinancegate way.org $/ \mathrm{p} / \mathrm{site} / \mathrm{m} /$ library.

[36] Kathryn Harrison and Lisa McIntosh Sundstorm(2007) The Comparative Politics of Climate Change, Global Environmental Politics, Published by the Massachusetts Institute of Technology, available at www.mitpressjournals.org/doi/pdf/10.1162/glep.2007.7.4.1

[37] Siddique, Kaniz (2011) Domestic Violence Against Women : Cost to the Nation, Care-Bangladesh Research Report on Women Empowerment.

[38] Staff Correspondent (2014, March 20) Government, media must work together, The Daily Star. P.5.

[39] Khandker, et al (1955) cited in Abdul Hye, Hasnat (1996) Below the Line: Rural Poverty in Bangladesh, the University Press Limited, Dhaka.175-176.

[40] Khan, Mizan R, et al.(2002)Civil Society and Democracy in Bangladesh, Academic Press and Publishers Limited, Dhanmondi, Dhaka-1209, Bangladesh.

[41] Lewis, D.J. (1993) Overview in Non-Government Organizations and the State in Asia (J. Farrington and D. Lewis, eds) London: Routledge.

[42] Linz J, Stepan A. (1996) Problems of Democratic Transition and Consolidation. Johns Hopkins University Press: Baltimore

[43] Malena,Carmen And Finn Heinrich, Volkhart(2007) Can We Measure Civil Society? A Proposed Methodology For International Comparative Research. Development In
Practice, Vol. 17, No. 3 (Jun., 2007), Pp. 338-352.

[44] Mahbubur Rahman et al (1996) Proliferation of NGOs in Bangladesh: A Critical Analysis

[45] Mizan, Ainon Nahar(1994)In Quest of Empowerment : The Grameen Bank Impact on Women's Power and Status, The University Press Limited, 114 Motijheel C/A, Dhaka-1000, Bangladesh.

[46] Miranda A. Schreurs and Yves Tiberghien (2007)Multi-level Reinforcement: Explaining European Union Leadership in Climate Change Mitigation, Global Environmental Politics, Volume 7, Number 4, November 2007,pp. 19-46 (Article), Published by The MIT Press.

[47] Neera Chandhoke(2003)The Conceits of Civil Society, Oxford University Press, New Delhi, India.

[48] Nehginpao Kipgen(2014, March 20) Optimism on Myanmar's Transition. The Daily Star(National ed.)P.07.

[49] Ozdemder, SuleymanAndParlak, Zeki(2009) The Increasing Importance Of The Civil Society Organizations (CSOs). International Symposium On Sustainable Development, June 9-10 2009

[50] Pearce, Jenny (2004)Development, NGO's and Civil Society : The Debate and Its Future, Oxfam GB, ISBN 0855984422.

[51] Rahman,Atiour(1999 )NGOs And Civil Society In Bangladesh.The Journal of Social Studies.No 84.

[52] Raymond J. Struyk (2003)Contracting with NGOs for Social Services, The Urban Institute, p. 3

[53] Richard Holloway (1998) Supporting Citizens Initiatives, Intermediate Technology Publications Limited, 103-105 Southampton Row, London WC1B 4HH, UK.

[54] Reimann, Kim D, (2005) Up to No Good? Recent Critics and and Critiques of NGOs, Political Science Faculty Publications. Paper 5.

[55] Shamim Hamid(1996)Why Women Count: Essays on Women in Development in Bangladesh, The University Press Limited, 114 Motijheel C/A, Dhaka, Bangladesh.

[56] Stepan A. (1988) Rethinking Military Politics. Princeton University Press: Princeton

[57] Sudipta Kaviraj, et al.(2001)Civil Society : History and Possibilities, Cambridge University Press.The Edinburgh Building, Cambridge, CB2 2RU,UK.

[58] Sushama Sahay(1998)Women and Empowerment: Approaches and Strategies, Discovery Publishing House, New Delhi-110002, India.

[59] Solava Ibrahim and David Hulme (2010) Has Civil Society Helped the Poor? - A review of the roles and contributions of civil society to poverty reduction? BWPI, The University of Manchester, Humanities Bridgeford Street, Oxford Road,Manchester, M13 9PL.

[60] The Lancet, Volume 382, Issue 9906, Pages 1681 - 1682, 23 November 2013 doi:10.1016/S0140-6736(13)62294-1).

[61] Tvedt, T. (1998).Angels of Mercy or Development Diplomats?NGOs and Foreign Aid, Africa World Press, ISBN-10: 0865436754.

[62] Uphoff, Norman And Krishna, Anirudh(2004)Civil Society 
And Public Sector Institutions: More Thana Zero-Sum Relationship. Public Administration and DevelopmentPublic Admin. Dev. 24, 357-372.

[63] UNAIDS(2004)Issue Paper: What Constitutes a Right-based Approach? Definitions, Methods and Practices. UNAIDS Global Reference Group on HIV/AIDS and Human Rights; 4th Meeting 23-25 Auguste, 2004.

[64] Zohir, Sajjad(2004) NGO Sector in Bangladesh: An Overview,Economicand Political Weekly, Vol. 39, No. 36 (Sep. 4-10, 2004), Pp. 4109-4113.

[65] www.carebangladesh.org, visit on 15.11.2013

[66] www.dsd.gov.za/npo/index.php?option=com content\&task= view\&id=66\&Itemid $=114$, visit on 14.03 .14

[67] www.adb.org, visit on 14.11.2013

[68] www.brac.net, visit on 19.11.2013
[69] www.ngoab.gov.bd, visit on 22.11.2013

[70] www.blog.brac.net/2013/11/world-toilet-day-at-the-un ,visit on 22.11 .2013

[71] www.thelancet.com, visit on 22.11.2013

[72] www.uia.org, visit on 25.11.2013

[73] www.undp.org, visit on 10.03.2014

[74] www.unrisd.org/80256B3C005BF3C2/\%28httpPages\%29/1 889BA294D2950E08025791F005CD710?OpenDocument, visit on 14.03 .14

[75] www.worldbank.org/en/topic/socialdevelopment/overview , visit on 14.03.14.

[76] www. Wikipedia,visit on 10.11.13.

[77] Ahmad,Mokbul Morshed (2010) Understanding the South, Published by courtesy of Social Science Research Council, National University of Ireland, Galway, Ireland 